Marquette University

e-Publications@Marquette

College of Nursing Faculty Research and

Publications

Nursing, College of

$5-1-2012$

Predictors of New Graduate Nurses'

Organizational Commitment During a Nurse

Residency Program

Marilyn Meyer Bratt

Marquette University, marilyn.bratt@marquette.edu

Holly M. Felzer

Marquette University, holly.felzer@marquette.edu

Accepted version. Journal for Nurses in Staff Development, Vol. 28, No. 3 (May/June 2012): 108-119.

DOI. (C) 2012 Lippincott Williams \& Wilkins. Used with permission. 


\title{
Predictors of New Graduate Nurses' Organizational Commitment During a Nurse Residency Program
}

\author{
Marilyn Meyer Bratt \\ College of Nursing, Marquette University, \\ Milwaukee, WI \\ Holly M. Felzer \\ College of Nursing, Marquette University, \\ Milwaukee, WI
}

\section{Introduction}

Nurse residency programs, focused on transitioning newly licensed nurses to practice, are an evolving strategy to retain recently graduated nurses' and build their practice expertise to ensure the safe delivery of care. These transition-to-practice programs aim to address new nurses' lack of practice readiness and difficult role transition, and buffer the effects of negative work environments. Ineffective transition and stressful work environments are key factors causing job dissatisfaction and turnover in these beginning practitioners. Nurse residency programs provide extended opportunities to model professional role behaviors for new nurses, enhance knowledge development and clinical application, and promote successful integration to the work environment (Bratt, 2009). Despite these 
benefits, only $21 \%$ of new graduates reported having a formal internship or residency program and six percent had no formal orientation (Kovner et al., 2007).

Most recently, in a national survey of RNs conducted by the Department of Health and Human Services (2010), it was revealed that almost $40 \%$ of new graduates plan to leave their current positions within three years and almost $22 \%$ had already changed position or employer. For those new nurses who left their position the majority of the reasons $(73 \%)$ centered on issues related to the characteristics of the workplace with stressful work environment being cited most frequently followed by lack of good management and inadequate staffing.

Accreditation organizations including the Commission on Collegiate Nursing Education (2008) and the National Council of State Boards of Nursing (NCSBN, 2009a) have advocated for the development of transition to practice programs for newly graduated nurses. Additionally, the recently released Institute of Medicine report (2010) put forth a key recommendation for organizations to provide nurse residency programs for newly licensed nurses. This report also advocates for the need to evaluate the outcomes of these programs including their influence on patient outcomes and the retention and competency development of new nurses.

\section{Background for the Study}

Stimulated by new graduate turnover rates that ranged from 16 - $67 \%$ and an average nurse replacement cost of $\$ 65,000$, the typical salary of an entry level RN, a group of urban and rural acute care organizations launched the Wisconsin Nurse Residency Program (WNRP) for recently graduated nurses in 2005 (Bratt, 2009). Creation of this transition to practice program was driven by the observed challenges that new graduates' encounter during their first year, which has been well explicated in the literature (Berkow, Virkstis, Stewart, \& Conway, 2008; Duchscher, 2008; Fink, Krugman, Casey, \& Goode, 2008; Kramer, 1974; Pellico, Brewer, \& Kovner, 2009; Romyn et al., 2009; Spector \& Li, 2007). 
Jointly developed through an academic-service partnership, made possible with federal funding, the WNRP was envisioned to prevent the "flight of newly graduated nurses" by attending to critical factors that lead to new graduate nurse turnover. Driven by an understanding of the new graduate role transition and the challenges that are inherent in the transition experience, the residency program employed various modalities to ease the transition experience. Professional development education sessions, designed to build new graduates' practice expertise and provide a social support system, and mentors/coaches to further enhance role effectiveness and decrease stress were key elements of the program (Bratt, 2009). Theoretical underpinnings for the residency program were Benner's novice to expert model (1984) and new graduate transition theory (Duchscher, 2008; Duchsher \& Cowin, 2004; Kramer, 1974).

Healthcare organizations have been increasingly challenged to design appropriate programs that offer support for new graduates to ease their transition into practice (Beecroft, Kunzman, Krosek, 2001; Blanzola, Lindeman, \& King, 2004; Bratt \& Felzer, 2010; Goode \& Williams, 2004; Krugman et al., 2006; Lindsey \& Kleiner, 2005; Marcum \& West, 2004; Owens et al., 2001; Rosenfeld, Smith, Iervolino, \& Bowar-Ferres, 2004; Williams, Sims, Burkhead, \& Ward, 2002). These programs are intended to address pervasive difficulties that new graduates face as they enter professional practice and help them develop competency to effectively respond to the challenging, dynamic situations encountered daily. Studies have shown that the quality of new graduates' transition experience affects retention (Williams, Goode, Krsek, Bednash, \& Lynn, 2007), and the quality of the work environment impacts new nurses' turnover intent (Beecroft, Dorey, \& Wenten, 2008). However, the evidence base surrounding transition to practice/nurse residency programs is still evolving. Based on this, the present study sought to determine whether new graduates' personal characteristics, factors associated with job onboarding, and the work environment ultimately influences new nurses' organizational commitment. 


\section{Organizational Commitment, Job Satisfaction, Stress and Turnover}

Organizational commitment (OC) can be defined as identification with and involvement in a particular organization (Mowday, Steers, \& Porter, 1979; Porter, Steers, Mowday \& Boulain, 1974). The construct of $\mathrm{OC}$ is further classified by three distinct components: affective, continuance, and normative commitment (Meyer \& Allen, 1991). Of particular interest is that the affective component involves wanting to stay in an organization rather than out of a need to remain or an obligation. Meyer and Allen (1991) suggest that work experiences have predominant influence on affective commitment and when the work experience is positive, individuals desire to exert effort on behalf of the organization.

According to Mowday (1977) OC has three antecedents: personal characteristics, job characteristics, and work experiences. Each of these antecedents influence commitment, which then leads to behavioral outcomes including intent to remain in the organization. Viewed as an attitudinal measure, it is a more global holistic feeling towards the organization, whereas job satisfaction is more specifically linked to characteristics of the work environment. As such, $\mathrm{OC}$ is postulated to be more stable over time as compared to job satisfaction (Mowday et al., 1979) and is a key variable that influences turnover behavior (Liou, 2009). Organizational commitment has also been identified as an effective predictor of turnover and is a useful variable in studies exploring factors related to nurse retention (Wagner, 2007).

The provision of training for employees has been demonstrated to be related to OC (Bartlett, 2001). Particularly, perceived access to training, social support for training from senior staff, motivation to learn, and perceived benefits of training have been shown to have the strongest relationships with the affective form of OC. However, the relationship between perceived access to training and affective commitment has been found to be moderated by job satisfaction.

Organizational commitment has been shown to be positively related to job satisfaction (Blegen, 1993; Knoop, 1995; Tai, Bame, \& Robinson, 1998) and negatively related to turnover (Liou, 2009; 
Mowday et al., 1979; Wagner, 2007) or intent to leave (Lynn \& Redman, 2005). It has been suggested that job satisfaction indirectly influences turnover intent through its effects on OC (Lum, Kervin, Clark, Reid, \& Sirola, 1998). Studies have shown that OC is influenced by variables such as job stress, workplace empowerment, and transformational leadership (Blegen, 1993; Boyle, Bott, Hansen, Woods, \& Taunton, 1999; Gregory, Way, Lefort, Barrett, \& Parfrey, 2007; Hinshaw \& Atwood, 1985; Irvine \& Evans, 1995; Laschinger, Finegan, \& Shamian, 2001; Lum et al., 1998; Parasuraman, 1989; Price \& Mueller, 1981). Beecroft et al., (2008) found that when nurses feel committed to their organization and are satisfied with their job, turnover intent decreases. Along similar lines, Laschinger and colleagues (2001) found that a sense of empowerment influenced trust in management resulting in increased job satisfaction and commitment.

Nurses new to practice have high levels of stress up to nine months after hire (Beecroft et al., 2008; Bratt \& Felzer, 2010; Fink et al., 2008; Williams et al., 2007). New graduates struggle with organizational skills, juggling a large patient load, interacting with physicians, and managing the steep learning curve associated with new situations and procedures all of which are key sources of stress (Oermann \& Moffitt-Wolf, 1997). Job stress is a key factor that has the potential to influence the comfort that nurses perceive in relationship to their work experience. As job stress increases, job satisfaction decreases, leading to increased turnover intention (Larrabee et al., 2009).

Demographic variables represent certain dimensions of the individual and are considered one of the antecedents of OC (Meyer \& Allen, 2001; Steers, 1977). Variables such as age, experience, and education have been directly or indirectly linked to anticipated turnover/intent to leave and commitment in studies of nurses (Coomber \& Barriball, 2007; Hayes, Bonner, \& Pryor, 2006; Ingersoll, Olsan, Drew-Cates, DeVinney, \& Davies, 2002; Lucas, Atwood, \& Hagaman, 1993; Ma, Lee, Yang, \& Chang, 2009; Wagner, 2010). Additionally, characteristics of the job, another antecedent of OC, such as shift worked and setting have been linked to anticipated turnover, 
however often mediated through job stress or job satisfaction (Beecroft et al., 2008; Hayes et al., 2006; Lucas et al., 1993).

\section{Study Model: Theoretical Framework for the Study}

This study was based on an investigator-developed model that represents the theoretical linkages of a nurse residency program, new nurse transition to practice experience, and OC (Liou, 2008; Mowday et al., 1979; Meyer \& Allen, 2001). The theoretical framework also evolved from previous studies of nurse turnover (Hinshaw \& Atwood, 1985; Parsuraman, 1989; Price \& Mueller, 1981). Found in Figure 1, the framework consists of the outcome of $\mathrm{OC}$ and the three postulated antecedents including personal characteristics, job characteristics, and work experience.

\section{Research Aim}

The purpose of this study was to determine predictors of organizational commitment (OC) during a 12 month new graduate nurse residency program. Predictors of interest included personal characteristics of age, education, GPA, and anticipatory role socialization; job characteristics of job expectation, months in current job, and number of hours/week worked; and work experience including orientation experience (number of preceptors and weeks precepted, satisfaction with orientation), work environment (perceptions of job satisfaction, job stress), and job competence (clinical decision-making, nursing role performance). Specifically, the research aims were to investigate the predictive relationships among: 1.) Personal characteristics, job characteristics, work experience, and nurse residents' $O C$ at the beginning of the residency program; 2.) Work experience and nurse residents' $\mathrm{OC}$ at program midpoint and endpoint. 
NOT THE PUBLISHED VERSION; this is the author's final, peer-reviewed manuscript. The published version may be accessed by following the link in the citation at the bottom of the page.

\section{Methodology}

\section{Design and Sample}

This study was part of a series of investigations surrounding new graduate nurses' transition to practice experiences (Bratt, 2009; Bratt \& Felzer, 2010). The study reported here used a longitudinal correlational design with data collected from 16 different cohorts of nurse residents over a three-year period from 2005-2008 (Bratt, 2009). Study participants were newly licensed registered nurses practicing in rural and urban hospitals who took part in a 12 month nurse residency program that began approximately three months after hire. These participants were employed in over 40 different Midwestern acute care settings including large multi-hospital systems, communitybased hospitals, and critical access hospitals.

\section{Instrumentation}

\section{Personal Characteristics and Job Characteristics Constructs}

Consistent with the constructs outlined in the theoretical framework, three groups of predictor variables were measured as found in Figure 1. Personal Characteristics and Job Characteristics variables were measured by an investigator developed demographic questionnaire. Personal Characteristics, included demographics (age, gender, race) and pre-licensure education (degree, prior non-nursing degree, GPA, prior healthcare experience, role socialization theory course, and clinical experience with a preceptor). Job Characteristics were reflective of the new graduate onboarding process and included characteristics of the position (whether in the position desired, hospital setting, unit type, months in current job, hours worked per week, and type of shift) and characteristics of orientation (hours of classroom orientation, number of weeks precepted, number of preceptors, and whether orientation objectives were met). 
NOT THE PUBLISHED VERSION; this is the author's final, peer-reviewed manuscript. The published version may be accessed by following the link in the citation at the bottom of the page.

\section{Work Experience Construct}

Work Experience included perceptions of the work environment (job satisfaction and job stress) and job competence (clinical decision making and nursing role performance). Two instruments measured Work Environment. The Nurse Job Satisfaction Scale (NJS) (Hinshaw \& Atwood, 1985) measures elements that are important to enjoying or liking one's job. This scale contains 23 items on a five-point Likert Scale ( 1 = strongly disagree; 5 = strongly agree) and is comprised of three subscales including quality of care, enjoyment, and time to provide care (for the study sample, total scale $a=0.90$; subscales $a=$ $0.77-0.90)$. In prior literature with nurse samples, reliability was 0.78 (Hinshaw \& Atwood, 1985) and 0.86 (Bratt, Broome, Kelber, \& Lostocco, 2000). The second instrument, Job Stress Scale (JS) (Hinshaw \& Atwood, 1985), measures stress that is perceived in relation to one's job and work environment. This 22-item scale is rated on a four-point Likert scale ( $1=$ always; $4=$ rarely $)$ and is comprised of four subscales: competence, physical work environment, staffing, and team respect (for the study sample, total scale $a=0.87$; subscales $a=0.64-0.81$ ). The higher the scale score, the higher the level of perceived stress. Reliability estimates are similar to prior reports of 0.78 (Hinshaw \& Atwood, 1985) and 0.85 (Bratt et al., 2000).

Job Competence, the final element of Work Experience, involves new graduates' perception of their practice competency and was measured by two instruments. The first, Clinical Decision Making in Nursing Scale (Jenkins, 1985), is 40-item instrument rated on a fivepoint Likert scale $(1=$ never; $5=$ always $)$ that measures the conscious, cognitive method of how one goes about making decisions including searching for alternatives and options, canvassing objectives and values, evaluating and reevaluating consequences, and searching for information and unbiased assimilation of new information. Total scale Cronbach's alpha for the study sample was $0.82-0.83$ similar to previously reported estimates of 0.78 (Girot, 2000; Jenkins, 1985).

The second instrument, the Modified 6-D Scale of Nursing Performance, is a measure of the quality of nursing performance. The original scale (Six-D Scale; Schwirian, 1978) was revised by 
Marshalleck (1997) by adding a subscale of managing/outcomes, which addresses nursing behaviors that are results oriented, influence the effectiveness of the unit, and reduce costs. The scale contains 61 items and respondents indicate how well they can perform activities associated with nursing practice on a five-point Likert scale ( $0=$ not applicable; 4 = very well). The seven subscales measure performance associated with: critical care, interpersonal relations/communications, leadership, managing/outcomes, planning/evaluation, professional development, and teaching/collaboration. Prior reports of reliability estimates ranged from $0.86-0.95$ for the total scale and subscales $0.79-0.98$ (Marshallek, 1997; Schwirian, 1978). For this study sample Cronbach's alpha for the total scale was 0.95 and the subscales ranged from $0.71-0.90$.

\section{Outcome Variable: Organizational Commitment}

The Organizational Commitment Questionnaire (Mowday et al., 1979) measures the relative strength of an individual's identification with and involvement in a particular organization. The instrument is comprised of 15 items on a seven-point Likert scale ( $1=$ strongly disagree; $7=$ strongly agree). Numerous studies have employed this instrument with reported alpha coefficients ranging from $0.82-0.90$ (Beecroft et al., 2001; Mowday et al., 1979). Reliability estimates for the study sample was $a=0.90$.

\section{Data Collection Procedures}

Participating hospitals with existing Institutional Review Boards (IRB) approved the study. For hospitals without an internal IRB, approval was obtained from the IRB of the primary investigator's university. Respondents were provided with verbal and written explanations of the study and informed consent was obtained. Data were collected during a regularly scheduled residency program education session at program start (Time 1, T1), 6 months (Time 2, T2), and 12 months at program end (Time 3, T3). All new graduates in the residency program (2005-2008) were invited to be involved with $59 \%$ agreeing to participate. At the first data collection point (T1), $85 \%$ completed the research packet, $72 \%$ at T2, and $68 \%$ at T3. Data 
were collected by study site coordinators and research assistants and returned to the PI for data analysis.

\section{Data Analysis}

Descriptive and inferential statistical methods were employed to analyze the data using standard statistical software. Preliminary analyses were conducted to insure there were not violations of the assumptions of normality, linearity, and multicollinearity.

For research aim 1, separate multiple regression equations were calculated to explore the relationship of personal characteristics, job characteristics, and work experience as predictor variables of OC at baseline or Time 1 (T1) (Table 2; models 1a, 1b, 1c). Subscales of significant predictors in models $1 \mathrm{a}, 1 \mathrm{~b}$, and $1 \mathrm{c}$ were entered into a final model (1d) for T1. For research aim 2, multiple regression equations were calculated to explore how the ongoing work experience) contributed to $\mathrm{OC}$ at program midpoint (T2) and program end (T3) (models $2 a$ and $2 b$ respectively). Final models for T2 and T3 included hospital setting and subscales of significant predictors in the preliminary model for T2 and T3.

Since personal and job characteristics were collected only at baseline, it is unknown whether these characteristics changed over time. Therefore, they were not included in these final models. However, due to the program structure, hospital setting (urban vs. rural) was found to be significant in previous models and remained a stable characteristic over time and was included in the final T2 and T3 analysis. The use of subscale scores in the final models for each time was intended to provide a more detailed analysis to give clearer direction for targeted interventions to enhance those elements which are most critical to OC.

\section{Results}

Sample characteristics of the nurse residents are presented in Table 1 . The one year retention rate of the entire aggregate cohort was $81 \%$, which was determined by the percent of nurse residents starting the program compared to those ending the program. The total

Journal for Nurses in Staff Development, Vol. 28, No. 3 (Jay/June 2012): pg. 108-119. DOI. This article is (C Lippincott Williams \& Wilkins, Inc. and permission has been granted for this version to appear in e-Publications@Marquette. Lippincott Williams \& Wilkins, Inc. does not grant permission for this article to be further copied/distributed or hosted elsewhere without the express permission from Lippincott Williams \& Wilkins, Inc. 
sample size was 468 participants with the majority being female with Associate Degrees working on medical-surgical units in urban hospitals. Mean scores for the key work experience variables (clinical decision-making, job satisfaction, job stress, and nursing performance) and OC were presented in a prior publication (Bratt \& Felzer, 2010).

\section{Research Aim 1}

The first three models $(1 \mathrm{a}-1 \mathrm{c})$ analyzed the significance of predictors of OC at T1 (program start). Results are presented in Table 2. Personal characteristics variables, the first model tested (1a), were found to be non-significant in predicting OC. Job characteristics, the next group of variables tested (1b), revealed three significant variables, in desired position, orientation objectives met, and hospital setting with the total model for job characteristics explaining $13 \%\left(R^{2}\right.$ $=.13$ ) of the variance in OC.

In the third model (1c), work experience variables were entered. Nursing job satisfaction (NJS) and job stress (JS) together explained $31 \%\left(R^{2}=.31\right)$ of the variance in OC. In the final model (1d) predicting OC at T1, hospital setting $(\beta=.15)$ and position hoped for $(\beta=.09)$, along with the subscales NJS enjoyment $(\beta=.47)$, JS physical environment $(\beta=-.11)$ and JS staffing $(\beta=-.16)$ were found to be significant. The entire model explained $40 \%$ of the variance in $\mathrm{OC}$ at the beginning of the nurse residency program.

\section{Research Aim 2}

To predict OC at program midpoint work experience variables were entered ( $2 a)$. Similar to the model at T1, NJS $(\beta=.34)$ and JS ( $\beta$ $=-.26)$ were found to be significant with all the variables explaining $32 \%$ of the variance. Similarly, for T3 work experience variables were entered resulting in a model $(2 \mathrm{~b})$ that was comparable to T2, NJS ( $\beta=$ .38 ) and JS ( $\beta=-.18$ ) were found to be significant explaining $30 \%$ of the variance.

The final two models ( $3 a, 3 b)$ examined significant predictors at T2 and T3. The final model for T2 (3a) explained $43 \%$ of the variance in $\mathrm{OC}$, with hospital setting remaining significant along with the work 
experience subscales NJS enjoyment, JS team respect, and JS staffing. This analysis was replicated entering hospital setting and the subscales of NJS and JS to determine predictors of OC at T3 (program end). In the final model at T3 (3b), significant predictors of OC were hospital setting, NJS enjoyment, and JS physical environment. This final model predicted $43 \%$ of the variance in OC at program end.

\section{Discussion}

\section{Personal and Job Characteristics}

Personal characteristics were not found to be significant predictors of OC, which is contrary to other studies which have identified factors such as age and degree to be influential in predictive models of OC (Beecroft et al., 2008; Liou, 2008; Lum et al., 1998; Steers, 1977). Even though certain demographic characteristics are linked to the constructs of turnover and commitment, their predictive ability remains inconclusive (Meyer \& Allen, 1991; Tai et al., 1998). Hospital setting (urban vs. rural) was found to be influential of OC at all three time periods, with urban nurses having higher levels of commitment compared to rural nurses. This is contrary to the findings cited by Ingersoll et al. (2002). In their study of job satisfaction and commitment of nurses in New York, the authors reported that nurses practicing in urban areas were less committed than their counterparts working in rural areas.

Rural nurses' scope of practice tends to be less specialized (McCoy, 2009) and rural nurses may experience greater professional isolation (Beatty, 2001; Shreffler, 1998; Winters \& Mayer, 2002). Rural settings often lack monetary resources and professional support to assist new graduates, which could lead to turnover intent (Jukkala, Henly, \& Lindeke, 2008). Further, differences in commitment to the organization may be dependent on other factors such as satisfaction with rural life, rural background, and family ties or connection to the community (Bushy, 2002; Roberge, 2009).

Initial job placement in the new graduate's desired position was found to be a significant predictor of OC. Individuals come to an organization with certain expectations and if these expectations are 
met commitment will be enhanced (Meyer \& Allen, 1991; Steers, 1977) and job satisfaction increases (Williams \& Hazer, 1986). Not receiving the first choice of unit assignment has been associated with higher turnover intent (Beecroft et al., 2008). Knowledge of new graduates' preference for their first position will help to earmark those that have greater potential to be less satisfied and leave the organization.

Educational support of new graduates' transition to practice, such as through nurse residency programs, is important to their success (Bratt, 2009; Goode, Lynn, Krsek, \& Bednash, 2009). Meeting the objectives of the orientation period is an important outcome of the onboarding process, which includes focused supervision by experienced preceptors; however, participant perceptions of meeting orientation objectives was not predictive of OC when entered with work experience variables. Likewise, the number of weeks precepted and the number of preceptors new graduates had did not influence OC. However these factors may have some mediating effects on work experience variables such as job satisfaction and job stress. Even though it has been suggested by regulatory agencies (NCSBN, 2009b) that new graduates have consistent, dedicated preceptors throughout the orientation process, the influence of this practice on their commitment to the organization requires further investigation.

\section{Work Experience}

The finding that work experience variables had a major influence on $\mathrm{OC}$ is consistent with previous reports in the literature (Steers, 1977). Enjoyment was the key element of job satisfaction that was most influential in predicting OC. This is supported by Beecroft et al. (2008) who found that lower enjoyment scores were associated with higher turnover intent. Likewise, Boyle et al. (1999) found that in a study of critical care nurses, that job satisfaction/enjoyment had a strong link to intent to stay. Viewing OC from an affective perspective implies that individuals stay in organizations because they desire to (Meyer \& Allen, 1991). Therefore it is not surprising that if new graduates find pleasure in and like their job they will be more committed to the position and wish to remain. 
Job stress was found to be a relatively strong predictor of OC at all three time periods. Of concern is that it has been reported that over $85 \%$ of new graduates experience moderate to high levels of stress in the year prior to hire (Symes et al., 2005). This pre-existing level of stress can compound the challenges new graduates face during the first year of experience. Three job stress subscales were found to be significant although at different measurement points. These elements of stress reflected both personal/internally perceived stress (feelings of competence and being respected by the team for that competence) and situational stress caused by factors in the environment such as adequacy of staffing and availability of supplies. Situational and personal stress has been shown to be linked to job satisfaction and intent to stay (Larrabee et al., 2009) and commitment indirectly through job enjoyment (Taunton, Boyle, Woods, Hansen, \& Bott, 1997). The mediating effects of work setting characteristics, such as stress, on OC or intent to stay through effects on job satisfaction have also been found in other studies (Boyle et al., 1999; Gaertner, 1999; Price \& Mueller, 1981).

At T1 situational-based stress related to adequacy of staffing to deliver care and having a satisfying schedule (Staffing subscale) and stress related to having an appropriate work environment, space and availability of equipment/ supplies to deliver care (Physical Work Environment subscale) were most predictive of OC. At T2 situational stress (Staffing subscale) and personal stress (Team Respect subscale) were predictive, underscoring the need for continued mentoring to build confidence and skill related to personal competency, such as a nurse residency program. At T3, situational stress (Physical Work Environment subscale) was more predictive of OC.

Understanding the importance of these variables over time may be best explained by theories that illuminate the evolution of new graduates' professional practice and first-year experiences including Benner's hallmark study of expert nurses' skill acquisition and knowledge (1984), Kramer's reality shock model (1974), and Duchsher's stages of new graduate role transition (2008). New graduates as they begin practice are characterized as advanced beginners and perceive their work as a set of tasks that need 
completing and perceive that their knowledge and skills are constantly challenged (Benner, Tanner, \& Chesla, 2009). This could account for the finding that predominant sources of stress that influence $\mathrm{OC}$ at the first two measurement points is reflective of the new graduates' focus on skills and the desire for a work environment that supports their ability to complete their list of tasks, such as having enough staff and access to needed resources.

Similarly Duchsher's model (2008), advanced through qualitative methodologies, views transition to practice as a transformative process whereby new graduates increase their level of knowledge and scope of practice and undergo professional growth. A process of "becoming" is the overarching theme of the model whereby the new graduate moves through stages of Doing, Being, and Knowing over a 12-18 month period. In the Doing phase, similar to Benner's advanced beginner stage, new graduates are in the throes of learning and performing whereby they are focused on "understanding what was expected of them, doing it well, and completing their tasks on time" (Benner, et al., 2009, p. 44) and finding their knowledge base and clinical performance scrutinized. During the ensuing five to seven months into the transition period, Duchsher asserts that a "crisis of confidence" peaks and is characterized by new graduates' heightened insecurities regarding their competence. During the middle of the first year, new graduates are still striving to develop their role competency and assume a valued role on the team. This could explain why at program midpoint (T2) personal stress driven from a sense of being respected by the team becomes a variable important to OC.

Finally, at program endpoint (T3), only stress related to the physical work environment remained influential in predicting OC. Perhaps the best explanation of this is that it represents that new graduates have moved beyond their lapses in self-confidence and stress driven from their evolving competency to concern for delivering care that they perceive is important to their patients. Duchsher proposes that during the final phase of transition, at approximately 12 months, new graduates are confident and competent in their nursing role and sources of stress shift from an internal focus on their role and responsibilities to external sources of stress resulting from their difficulties dealing with the larger health care system. At this point in 
their transition experience, new graduates find themselves having full patient loads and may be taking on additional responsibilities such as charge positions or preceptoring other new nurses and students. This may place additional burdens on managing the care for their assigned patients resulting in higher levels of stress if they don't have what they need to deliver that care, which ultimately can influence enjoyment of their job and commitment.

A specific outcome of the study participants' involvement in the nurse residency program was to increase their ability to deliver competent care. It was also postulated that the strategies employed to advance their role competency would result in increased selfconfidence, thereby decreasing job stress and enhancing job satisfaction, which would increase commitment to the organization. A direct link between job competence and OC was not found in the current study. This was contrary to Beecroft and colleagues (2008) who did find support for a relationship between perceptions of competence and turnover intent in a sample of pediatric new graduate nurses. Nurses who reported lower ratings on competency and selfconfidence in relationship to skill performance had higher turnover intent.

It is possible that new graduates' assessment of their competence, as measured by perceptions of clinical performance and decision-making, are not directly associated with commitment. Rather, these variables may be exerting influence through job stress, particularly since a component of stress is derived from feelings of personal competence and being respected as a member of the team (Hinshaw \& Atwood, 1985). This may explain why the competence measures lost explanatory power. Perhaps another measure of job competence or role self-confidence would have provided more explanatory power in predicting OC.

\section{Strengths and Limitations}

Drawing the sample from urban and rural hospitals that included large teaching hospitals and community and critical access hospitals was a primary strength of this study. This sampling enhances the robustness and increases the generalizability of the findings. The 
longitudinal design, collecting data over one year, enabled a more complete examination of the experience of new graduates across time rather than a single snapshot, which fostered the uncovering of unique patterns in their experiences.

Even though the regression models were relatively explanatory it is evident that there are additional variables that should be tested. Variables pertaining to new graduates' perceptions of leadership, ongoing support, unit culture, and empowerment may have added explanatory power. Since job characteristic variables were not measured beyond the baseline measure (other than hospital setting) it is unknown how these characteristics may have influenced OC over time. Finally, even though $\mathrm{OC}$ has been found to be associated with turnover, it is unknown what the true relationship is in this population since individual-level turnover data were not collected.

\section{Conclusions: Implications for Practice}

New graduates come to their first job experience with preexisting ideas of where they want to work. If these expectations are not met, new nurses may be less committed to the organization and seize opportunities to seek new employment that better matches their desired job. Based on this, during the hiring process, care should be exercised to determine new graduates' preference for job placement. New nurses not receiving their practice setting of choice require more careful monitoring and attention to their attitudes toward their job.

Since characteristics of the work environment are the most pervasive factors influencing new graduates' OC over time, strategies should be put into place that bolster new graduates' job satisfaction and diminish their perception of stress. Throughout the first year, new graduates' perception of job stress is particularly critical. Much of this stress results from challenges associated with their perception of their developing competency as it relates to the rest of the team as well as their ability to have the tools and resources to deliver care. Creating work environments that are conducive to fostering learning and professional development are crucial to increasing graduates' confidence and competence. New graduates' stress resiliency and ability to adapt can be enhanced by nurse residency programs which 
are theory-driven and employ best practice methods that serve to close the practice gap. Ultimately, this increases psychological empowerment, decreases stress, and increases job satisfaction which eventually leads to decreased turnover intent (Larrabee et al., 2009).

Future research needs to be conducted to further explore the differences between urban and rural settings to understand the unique influence of employment setting on OC. Moreover, further exploration of other predictive variables of new graduates' commitment is warranted. Investigation of workplace factors such as organizational culture (Gregory et al., 2007), nursing leadership (Coomber \& Barriball, 2007), empowerment and engagement (Laschinger et al., 2001; Laschinger, Wilk, Cho, \& Greco, 2009) due to their reported influence on job satisfaction and retention are particularly warranted.

The tumultuousness of new graduates' transition to practice has been well documented. Effective onboarding practices and nurse residency programs that support new graduates' professional development need to be in place to address factors that negatively influence OC and cause eventual turnover. Effective transitioning programs can provide new nurses with additional tools to insure safe and competent delivery of care. Furthermore, these programs have the potential to reduce errors, build professional practice, promote leadership skills, and minimize burn-out and turnover. In particular, these programs should be directed towards reducing stress, resulting from internal self-doubt regarding capabilities, difficulty meeting the demands for rapid role assimilation, and managing the expected workload. Finally, if new nurses enjoy their job, they will be more likely to be committed to the values of the organization and remain in that organization. This will require appropriately managing new graduates' internal and external stressors generated from challenging work environments.

\section{Acknowlegements}

This study was supported by funds from the Division of Nursing (DN), Bureau of Health Professions (BHPr), Health Resources Services Administration (HRSA), Department of Health and Human Services (DHHS) under grants D64HP03092 (2004-2007) and D11HP08384 (2007-2010). 
NOT THE PUBLISHED VERSION; this is the author's final, peer-reviewed manuscript. The published version may be

\section{References}

Bartlett, K. R. (2001). The relationship between training and organizational commitment: A study in the health care field. Human Resource Development Quarterly, 12(4), 335-352.

Beatty, R. M. (2001). Continuing professional education, organization support and profession competence: Dilemmas of rural nurses. Journal of Continuing Education in Nursing, 32(5), 203-209.

Beecroft, P. C., Dorey, F., \& Wenten, M. (2008). Turnover intention in new graduate nurses: A multivariate analysis. Journal of Advanced Nursing, 62(1), 41-52.

Beecroft, P. C., Kunzman, L., \& Krozek, C. (2001). RN Internship: Outcomes of a one-year pilot program. Journal of Nursing Administration, 31(12), 575-582.

Benner, P. (1984). From Novice to Expert: Excellence and power in clinical nursing practice. Menlo Park, CA: Addison-Wesley.

Benner, B., Tanner, C., \& Chesla, C. (2009). Expertise in Nursing Practice: Caring, Clinical Judgment and Ethics ( $2^{\text {nd }}$ ed.). New York: Springer.

Berkow, S., Virkstis, K., Stewart, J., \& Conway, L. (2008). Assessing new graduate nurse performance. Journal of Nursing Administration, 38(11), 468-474.

Blanzola, C., Lindeman, R., \& King, M. L. (2004). Nurse internship pathway to clinical comfort, confidence, and competency. Journal for Nurses in Staff Development, 20(1), 27-37.

Blegen, M. A. (1993). Nurses' job satisfaction: A meta-analysis of related variables. Nursing Research, 42(1), 36-41.

Boyle, D. K., Bott, M. J., Hansen, H. E., Woods, C. Q., \& Taunton, R. L. (1999). Managers' leadership and critical care nurses' intent to stay. American Journal of Critical Care, 8(6), 361-371.

Bratt, M. M. (2009). Retaining our next generation of nurses: The Wisconsin nurse residency program providing a continuum of support. Journal of Continuing Education in Nursing, 40(9), 416425.

Bratt, M. M., \& Felzer, H. M. (2010). Perceptions of professional practice and work environment of new graduates in a nurse residency program. Submitted for publication August 14, 2010.

Bratt, M., Broome, M., Kelber, S., \& Lostocco, L. (2000). The influence of stress and nursing leadership on job satisfaction of pediatric 
intensive care nurses. The American Journal of Critical Care, 9(5), 307-317.

Bushy, A. (2002). International perspectives on rural nursing: Australia, Canada, USA. Australian Journal of Rural Health, 10, 104-111.

Commission on Collegiate Nursing Education. (2008). Standards for Accreditation of Post-Baccalaureate Nurse Residency Programs. Retrieved from http://www.aacn. nche.edu/accreditation/pdf/resstandards08.pdf Coomber, B., \& Barriball, K. L. (2007). Impact of job satisfaction components on intent to leave and turnover for hospital-based nurses: A review of the literature. International Journal of Nursing Studies, 44, 297-314.

Department of Health and Human Services Health Resources and Services Administration. (2010). The Registered Nurse Population: Findings from the 2008 National Sample Survey of Registered Nurses. Retrieved October, 25, 2010 from http://bhpr.hrsa.gov/healthworkforce/rnsurvey/2008/nssrn2008 .pdf.

Duchscher, J. B. (2008). A process of becoming: The stages of new nursing graduate professional role transition. Journal of Continuing Education in Nursing, 39(10), 441-450.

Duchscher, J. B., \& Cowin, L. S. (2004). The experience of marginalization in new nursing graduates. Nursing Outlook, 52, 289-296.

Duchscher, J. B., \& Myrick, F. (2008). The prevailing winds of oppression: Understanding the new graduate experience in acute care. Nursing Forum, 43(4), 191-206.

Fink, R., Krugman, M., Casey, K., \& Goode, C. (2008). The graduate nurse experience: Qualitative residency program outcomes. Journal of Nursing Administration, 38(7/8), 341-348.

Gaertner, S. (1999). Structural determinants of job satisfaction and organizational commitment in turnover models. Human Resource Management Review, 9(4), 479-493.

Girot, E. A. (2000). Graduate nurses: Critical thinkers or better decision makers? Journal of Advanced Nursing, 31(2), 288-297. 
Goode, C. J., Lynn, M., Krsek, C., \& Bednash, G. D. (2009). Nurse residency programs: An essential requirement for nursing. Nursing Economic\$,27(3), 142-159.

Goode, C. J., \& Williams, C. A. (2004). Post-Baccalaureate nurse residency program. Journal of Nursing Administration, 34(2), 71-77.

Gregory, D. M., Way, C. Y., LeFort, S., Barrett, B. J,. \& Parfrey, P. S. (2007). Predictors of registered nurses' organizational commitment and intent to stay. Health Care Management Review, 32(2), 119-127.

Hayes, B., Bonner, A., \& Pryor, J. (2010). Factors contributing to job satisfaction in the acute hospital setting: A review of recent literature. Journal of Nursing Management, 18, 804-814.

Hinshaw, A. S., \& Atwood, J. R. (1985). Anticipated turnover among nursing staff study: Final report. National Institutes of Health. National Center of Nursing Research. No. RO1NU00908.

Ingersoll, G. I., Olsan, T., Drew-Cates, J., DeVinney, B. C., \& Davies, J. (2002). Nurses' job satisfaction, organizational commitment, and career intent. Journal of Nursing Administration, 32(5), 250-263.

Institute of Medicine. (2010). Report Recommendations: The future of nursing: Leading change, advancing health. Retrieved November 30, 2010from

http://www.iom.edu/ /media/Files/Report\%20Files/2010/TheFuture-of-

Nursing/Future\%20of\%20Nursing\%202010\%20Recommendatio ns.pdf

Irvine, D. M., \& Evans, M. G. (1995). Job satisfaction and turnover among nurses: Integrating research findings across studies. Nursing Research, 44(4), 246-253.

Jukkala, A. M., Henly, S. J., \& Lindeke, L. L. (2008). Rural perceptions of continuing professional education. The Journal of Continuing Education in Nursing, 39(12), 555-563.

Jenkins, H. M. (1985). A research tool for measuring perceptions of clinical decision making. Journal of Professional Nursing, 1(4), 221-229.

Knoop, R. (1995). Relationship among job involvement, job satisfaction, and organizational commitment for nurses. The Journal of Psychology, 129(6), 643-649.

Journal for Nurses in Staff Development, Vol. 28, No. 3 (Jay/June 2012): pg. 108-119. DOI. This article is (C Lippincott Williams \& Wilkins, Inc. and permission has been granted for this version to appear in e-Publications@Marquette. Lippincott Williams \& Wilkins, Inc. does not grant permission for this article to be further copied/distributed or hosted elsewhere without the express permission from Lippincott Williams \& Wilkins, Inc. 
Kovner, C. T., Brewer, C. S., Fairchild, S., Poornima, S., Kim, H., \& Djukic, M. (2007). Newly licensed RN's characteristics, work attitudes, and intentions to work. The American Journal of Nursing, 100(11), 58-70

Kramer, M. (1974). Reality Shock: Why Nurses Leave Nursing. St. Louis, MO: CV Mosby.

Krugman, M., Bretschneider, J., Horn, P. B., Krsek, C. A., Moutafis, R. A., \& Smith, M. O. (2006). The national post-baccalaureate graduate nurse residency program: A model for excellence in transition to practice. Journal for nurses in staff development, 22(4), 196-205.

Larrabee, J. H., Wu, Y., Persily, C. A., Simoni, P. S., Johnston, P. A., Marcischak, T. L.,... \& Gladden, S. D. (2009). Influence of stress resiliency on RN job satisfaction and intent to stay. Western Journal of Nursing Research, 32(1), 81-102.

Laschinger, H. K. S., Finegan, J., \& Shamian, J. (2001). The impact of workplace empowerment, organizational trust on staff nurses' work satisfaction and organizational commitment. Health Care Management Review, 26(3), 7-23.

Laschinger, H. K. S., Wilk, P., Cho, J., \& Greco, P. (2009). Empowerment, engagement and perceived effectiveness in nursing work environments: Does experience matter? Journal of Nursing Management, 17, 636-646.

Lindsey, G., \& Kleiner, B. (2005). Nurse residency program: An effective tool for recruitment and retention. Journal of Health Care Finance, 31(3), 25-32.

Liou, S. R. (2009). Nurses' intention to leave: critically analyze the theory of reasoned action and organizational commitment model. Journal of Nursing Management, 17, 92-99.

Lynn, M. R., \& Redman, R. W. (2005). Faces of the nursing shortage: influences on staff nurses' intentions to leave their positions or nursing. Journal of Nursing Administration, 35(5), 264-270.

Lucas, M. D., Atwood, J. R., \& Hagaman, R. (1993). Replication and validation of anticipated turnover model for urban registered nurses. Nursing Research, 42(1), 29-35.

Lum, L., Kervin, J., Clark, K., Reid, F., \& Sirola, W. (1998). Explaining nursing turnover intent: Job satisfaction, pay satisfaction, or organizational commitment. Journal of Organizational Behavior, 19, 305-320. 
Ma, J., Lee, P., Yang, Y., \& Chang, W. (2009). Predicting factors related to nurses' intention to leave, job satisfaction, and perception of quality of care in acute care hospitals. Nursing Economic\$, 27(3), 178-184,202.

Marcum, E. H., \& West, R. D. (2004). Structured orientation for new graduates. Journal for Nurses in Staff Development, 20(3), 118124.

Marshalleck, E. F. (1997). The effect of education, job characteristics, and hospital unit structure on nurse performance and job satisfaction. (Unpublished doctoral dissertation). Stanford University.

McCoy, C. (2009). Professional Development in Rural Nursing: Challenges and Opportunities. The Journal of Continuing Education in Nursing, 40(3), 128-31.

Meyer, J. P., \& Allen, N. J. (1991). The three-component conceptualization of organizational commitment. Human Resource Management Review, 1(1), 61-89.

Mowday, R. M. (1977). Antecedents and outcomes of organizational commitment. Administrative Science Quarterly, 22, 46-56.

Mowday, R. T., Steers, R. M., \& Porter, L. W. (1979). The measurement of organizational commitment. Journal of Vocational Behavior, 14, 224-247.

National Council of State Boards of Nursing. (2009a). Description of NCSBN's Transition to Practice Model. Retrieved from https://www.ncsbn.org/TransitiontoPractice_modeldescription_1 11309.pdf .

National Council of State Boards of Nursing. (2009b). Report of Findings from the Post-Entry Competency Study. Research Brief, Vol. 38. Retrieved from https://www.ncsbn.org/09_PostEntryCompetenceStudy_Vol38.p $\mathrm{df}$

Oermann, M. H., \& Moffitt-Wolf, A. (1997). New graduates' perceptions of clinical practice. Journal of Continuing Education in Nursing, 28(1), 20-25.

Owens, D., Turjanica, M. A., Scanion, M., Sandhusen, A., Williamson, M., Hebert, C., \& Facteau, L. (2001). New graduate RN internship program: A collaborative approach for system-wide integration. Journal for Nurses in Staff Development, 17(3), 144-150. 
Parasuraman, S. (1989). Nursing turnover: An integrated model. Research in Nursing \& Health, 12, 267-272.

Pellico L. H., Brewer C. S., \& Kovner, C. T. (2009). What newly licensed registered nurses have to say about their first experiences. Nursing Outlook, 57(4), 194-203.

Porter, L. W., Steers, R. M., Mowday, R. T., \& Boulian, P. V. (1974). Organizational commitment, job satisfaction, and turnover among psychiatric technicians. Journal of Applied Psychology, 59, 603-609.

Price, J. L., \& Mueller, C. W. (1981). Professional Turnover: The Case of Nurses. Jamaica, New York: Spectrum Publications.

Roberge, C. M. (2009). Who stays in rural nursing practice? An international review of the literature on factors influencing rural nurse retention. Online Journal of Rural Nursing and Health Care, 9(1), 82-93.

Romyn, D. M. Linton, N., Giblin, C., Hendrickson, B., Limacher, J. H., Murray, C.,... Zimmel, C.M. (2009). Successsful transition of the new graduate nurse. International Journal of Nursing Education Scholarship, 6(1), 1-17.

Rosenfeld, P., Smith, M. O., Iervolino, L., \& Bowar-Ferres, S. (2004). Nurse resident program: A 5-year evaluation from the participant's perspective. Journal of Nursing Administration, 34(4), 188-194.

Schwirian, P. M. (1978). Evaluating the Performance of nurses: A multidimensional approach. Nursing Research, 27(6), 347-351.

Shreffler, M. J. (1998). Professional isolation: A concept analysis. In H.J. Lee (Ed.), Conceptual Basis for Rural Nursing ( $1^{\text {st }}$ ed., pp. 420-432). New York: Springer.

Spector, N., \& Li, S. (2007). A regulatory model on transitioning nurses from education to practice. JONA's Healthcare Law, Ethics, and Regulation, 9(1), 19-22.

Steers, R. M. (1977). Antecedents and outcomes of organizational commitment. Administrative Science Quarterly, 22(1), 4656.

Symes, L., Krepper, K. R., Lindy, C., Byrd, M. N., Jacobus, C., \& Throckmorton, T. (2005). Stressful life events among new nurses: Implications for retaining new graduates. Nursing Administrative Quarterly, 29(3), 292-296. 
Tai, T. W. C., Bame, S. I., \& Robinson, C. D. (1998). Review of nursing turnover research, 1977-1996. Social Science and Medicine, 47(12), 1905-1924.

Taunton, R. L., Boyle, D. K., Woods, C. Q., Hansen, H. E., \& Bott, M. J. (1997). Manager leadership and retention of hospital staff nurses. Western Journal of Nursing Research, 19(2), 205-226.

Wagner, C. M. (2007). Organizational commitment as a predictor variable in nursing turnover research: Literature review. Journal of Advanced Nursing, 60(3), 235-247.

Wagner, C. M. (2010). Predicting nursing turnover with catastrophe theory. Journal of Advanced Nursing, 66(9), 2071-2084.

Williams, C. A., Goode, C. J., Krsek, C., Bednash, G. D., \& Lynn, M. R. (2007). Postbaccalaureate nurse residency 1-year outcomes. Journal of Nursing Administration, 37(7/8), 357-365.

Williams, L. J., \& Hazer, J. T. (1986). Antecedents and consequences of satisfaction and commitment in turnover models: A reanalysis using latent variable structural equation methods. Journal of Applied Psychology, 71(2), 219-231.

Williams, T., Sims, J., Burkhead, C., \& Ward, P. M. (2002). The creation, implementation, and evaluation of a nurse residency program through a shared leadership model in the intensive care setting. Dimensions of Critical Care Nursing, 21(4), 154162.

Winters, C. A., \& Mayer, D. M. (2002). Special feature: An approach to cardiac care in rural settings. Critical Care Nursing Quarterly, 24(4), 75-82. 
NOT THE PUBLISHED VERSION; this is the author's final, peer-reviewed manuscript. The published version may be accessed by following the link in the citation at the bottom of the page.

Table 1: Sample Characteristics

\begin{tabular}{|c|c|}
\hline $\begin{array}{l}\text { Nurse Resident Demographic and Job Experience } \\
\text { Characteristics }\end{array}$ & $\begin{array}{l}\text { Total Sample } \\
\quad \mathrm{N}=468^{*}\end{array}$ \\
\hline & M (SD) \\
\hline Age & $29.96(8.3)$ \\
\hline Hours/week worked & $35.31(6.8)$ \\
\hline Months in Current Job & $6.8(5.1)$ \\
\hline GPA & $3.48(0.3)$ \\
\hline Length of classroom orientation (hours) & $50.74(69.5)$ \\
\hline Length of Precepted Experience (weeks) & $9.54(5.5)$ \\
\hline Number of Preceptors & $4.67(3.0)$ \\
\hline & N (\%) \\
\hline $\begin{array}{c}\text { Gender } \\
\text { Female } \\
\text { Male }\end{array}$ & $\begin{array}{r}428(94.3 \%) \\
26(5.7 \%)\end{array}$ \\
\hline Race & \\
\hline Asian & $3(0.7 \%)$ \\
\hline Black & $16(3.5 \%)$ \\
\hline Hispanic/Latino & $8(1.8 \%)$ \\
\hline White & $414(91.6 \%)$ \\
\hline More than one race & $11(2.4 \%)$ \\
\hline Degree & \\
\hline ADN & $250(55.4 \%)$ \\
\hline BSN & $201(44.6 \%)$ \\
\hline Prior Non-nursing Degree & \\
\hline Yes & $100(23.7 \%)$ \\
\hline No & $322(76.3 \%)$ \\
\hline Prior Healthcare Experience & \\
\hline Yes & $206(79.8 \%)$ \\
\hline No & $52(20.2 \%)$ \\
\hline In Desired Position & \\
\hline Yes & $332(78.5 \%)$ \\
\hline No & $91(21.5 \%)$ \\
\hline Type of Hospital & \\
\hline Rural & $86(18.4 \%)$ \\
\hline Urban & $382(81.6 \%)$ \\
\hline Shift Worked & \\
\hline Days & $95(22.8 \%)$ \\
\hline Evenings & $71(17.0 \%)$ \\
\hline Nights & $131(31.4 \%)$ \\
\hline Rotating & $120(28.8 \%)$ \\
\hline Type of Unit & \\
\hline Med-Surg & $243(57.4 \%)$ \\
\hline $\mathrm{OB}$ & $29(6.9 \%)$ \\
\hline ICU & $17(4.0 \%)$ \\
\hline ER & $15(3.5 \%)$ \\
\hline Surgical Services (OR, PACU, SDS) & $8(1.9 \%)$ \\
\hline Float & $1(0.2 \%)$ \\
\hline Other Specialties (e.g. Oncology) & $110(26.0 \%)$ \\
\hline Orientation Objectives Met & \\
\hline Yes & $363(89.0 \%)$ \\
\hline No & $45(11.0 \%)$ \\
\hline
\end{tabular}

*Ns for some analyses less than 468 due to missing data

Journal for Nurses in Staff Development, Vol. 28, No. 3 (Jay/June 2012): pg. 108-119. DOI. This article is (C) Lippincott Williams \& Wilkins, Inc. and permission has been granted for this version to appear in e-Publications@Marquette. Lippincott Williams \& Wilkins, Inc. does not grant permission for this article to be further copied/distributed or hosted elsewhere without the express permission from Lippincott Williams \& Wilkins, Inc. 
Table 2. Predictors of Organizational Commitment

\begin{tabular}{|c|c|c|c|c|c|c|}
\hline Models and Variables & Model Statistics & $\boldsymbol{\beta}$ & $\begin{array}{l}\text { SE } \\
\boldsymbol{\beta}\end{array}$ & $\begin{array}{l}\text { Standar- } \\
\text { dized } \beta\end{array}$ & $t$ & $\boldsymbol{p}$ \\
\hline $\begin{array}{l}\text { Model 1a: Participant } \\
\text { Personal Characteristics } \\
\text { Predictors }\end{array}$ & $\begin{array}{l}F(9,217)=1.03 \\
p=.415 R^{2}=.04\end{array}$ & & & & & \\
\hline $\begin{array}{ll}\text { a. } & \text { Age } \\
\text { b. } & \text { Gender } \\
\text { c. } & \text { Race }(0=\text { Non-white; } 1= \\
& \text { White }) \\
\text { d. } & \text { Prior Degree }(0=\text { No; } 1= \\
& \text { Yes }) \\
\text { e. Nursing Degree }(0= \\
\text { ADN; } 1=\text { BSN }) \\
\text { f. GPA } \\
\text { g. Prior Healthcare } \\
\text { Experience } \\
\text { ( } 0=\text { No; } 1=\text { Yes }) \\
\text { h. Role Socialization Theory } \\
\text { Course } \\
\text { ( } 0=\text { No; } 1=\text { Yes) } \\
\text { i. Clinical Experience with } \\
\text { Preceptor } \\
\text { (0=No; } 1=\text { Yes) }\end{array}$ & & & & & & $\begin{array}{l}\text { NS } \\
\text { NS } \\
\text { NS } \\
\text { NS } \\
\text { NS } \\
\text { NS } \\
\text { NS } \\
\text { NS } \\
\text { NS }\end{array}$ \\
\hline $\begin{array}{l}\text { Model 1b: Job } \\
\text { Characteristics Predictors }\end{array}$ & $\begin{array}{l}F(10,265)=3.8 \\
p<.001 R^{2}=.13\end{array}$ & & & & & \\
\hline 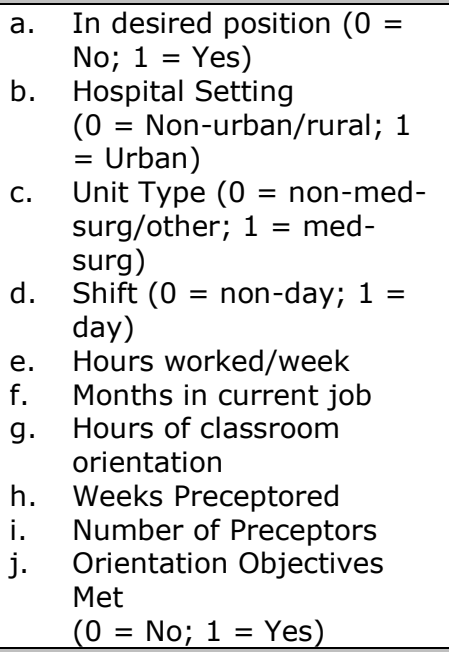 & & $\begin{array}{l}7.21 \\
4.55\end{array}$ & $\begin{array}{l}1.84 \\
2.03\end{array}$ & $\begin{array}{l}.23 \\
.14\end{array}$ & $\begin{array}{l}3.92 \\
2.24\end{array}$ & $\begin{array}{l}<.001 \\
.03 \\
\text { NS } \\
\text { NS } \\
\text { NS } \\
\text { NS } \\
\text { NS } \\
\text { NS } \\
\text { NS } \\
.001\end{array}$ \\
\hline $\begin{array}{l}\text { Model 1c: Work Experience } \\
\text { Predictors } \\
\text { Time } 1\end{array}$ & $\begin{array}{l}\mathrm{F}(4,290)=32.7 \\
\mathrm{p}<.001 \\
\mathrm{R}^{2}=.31\end{array}$ & & & & & \\
\hline $\begin{array}{l}\text { a. Clinical Decision-making } \\
\text { b. Job Satisfaction } \\
\text { c. Job Stress } \\
\text { d. Nursing Performance }\end{array}$ & & $\begin{array}{l}.52 \\
-.25\end{array}$ & $\begin{array}{l}.08 \\
.11\end{array}$ & $\begin{array}{l}.42 \\
-.15\end{array}$ & $\begin{array}{l}6.52 \\
- \\
2.31 \\
\end{array}$ & $\begin{array}{l}\text { NS } \\
<.001 \\
.02 \\
\text { NS } \\
\end{array}$ \\
\hline $\begin{array}{l}\text { Model 1d : Final Model } \\
\text { Time } 1\end{array}$ & $\begin{array}{l}\mathrm{F}(10,364))= \\
23.9, \mathrm{p}<.001 \\
\mathrm{R}^{2}=.40\end{array}$ & & & & & \\
\hline $\begin{array}{l}\text { Significant Predictors (Job } \\
\text { Characteristics and Work } \\
\text { Experience Subscale Scores) } \\
\text { a. Hospital setting } \\
\text { b. In desired position }\end{array}$ & & $\begin{array}{l}5.01 \\
2.90\end{array}$ & $\begin{array}{l}1.39 \\
1.35\end{array}$ & $\begin{array}{l}.15 \\
.09\end{array}$ & $\begin{array}{l}3.62 \\
2.15\end{array}$ & $\begin{array}{l}<.001 \\
.03 \\
\text { NS }\end{array}$ \\
\hline
\end{tabular}

Journal for Nurses in Staff Development, Vol. 28, No. 3 (Jay/June 2012): pg. 108-119. DOI. This article is (C Lippincott Williams \& Wilkins, Inc. and permission has been granted for this version to appear in e-Publications@Marquette. Lippincott Williams \& Wilkins, Inc. does not grant permission for this article to be further copied/distributed or hosted elsewhere without the express permission from Lippincott Williams \& Wilkins, Inc. 
NOT THE PUBLISHED VERSION; this is the author's final, peer-reviewed manuscript. The published version may be accessed by following the link in the citation at the bottom of the page.

\begin{tabular}{|c|c|c|c|c|c|c|}
\hline Models and Variables & Model Statistics & $\boldsymbol{\beta}$ & $\begin{array}{l}\text { SE } \\
\beta\end{array}$ & $\begin{array}{l}\text { Standar- } \\
\text { dized } \beta\end{array}$ & $t$ & $p$ \\
\hline \begin{tabular}{ccl} 
c. & \multicolumn{2}{c}{ Orientation objectives } \\
& met & \\
d. & Job Satisfaction \\
& i. & Enjoyment \\
& ii. & Quality of Care \\
& iii. & Time to Provide \\
& \multicolumn{2}{c}{ Care } \\
e. & Job Stress \\
& i. & Competence \\
& ii. & Physical \\
& ii. & Environment \\
& iii. & Staffing \\
& iv. & Team Respect \\
f. & Nursing & Performance
\end{tabular} & & $\begin{array}{l}-.54 \\
-.63\end{array}$ & $\begin{array}{l}.24 \\
.23\end{array}$ & $\begin{array}{l}-.11 \\
-.16\end{array}$ & $\begin{array}{l}- \\
2.24 \\
- \\
2.79\end{array}$ & $\begin{array}{l}<.001 \\
\text { NS } \\
\text { NS } \\
\text { NS } \\
.02 \\
.01 \\
\text { NS } \\
\text { NS }\end{array}$ \\
\hline $\begin{array}{l}\text { Model 2a: Work Experience } \\
\text { Predictors } \\
\text { Time } 2\end{array}$ & $\begin{array}{l}F(4,238)=28.33 \\
p<.001 \\
R^{2}=.32\end{array}$ & & & & & \\
\hline $\begin{array}{l}\text { a. Clinical Decision-making } \\
\text { b. Job Satisfaction } \\
\text { c. Job Stress } \\
\text { d. Nursing Performance }\end{array}$ & & $\begin{array}{l}.40 \\
-.39\end{array}$ & $\begin{array}{l}.08 \\
.11\end{array}$ & $\begin{array}{l}.34 \\
-.26\end{array}$ & $\begin{array}{l}5.10 \\
- \\
3.70\end{array}$ & $\begin{array}{l}\text { NS } \\
<.001 \\
<.001 \\
\text { NS }\end{array}$ \\
\hline $\begin{array}{l}\text { Model 2b: Work Experience } \\
\text { Predictors } \\
\text { Time } 3\end{array}$ & $\begin{array}{l}F(4,181)=19.50 \\
p<.001 \\
R^{2}=.30\end{array}$ & & & & & \\
\hline $\begin{array}{l}\text { a. Clinical Decision-making } \\
\text { b. Job Satisfaction } \\
\text { c. Job Stress } \\
\text { d. Nursing Performance }\end{array}$ & & $\begin{array}{l}.46 \\
-.26\end{array}$ & $\begin{array}{l}.10 \\
.12\end{array}$ & $\begin{array}{l}.38 \\
-.18\end{array}$ & $\begin{array}{l}4.77 \\
- \\
2.18\end{array}$ & $\begin{array}{l}\text { NS } \\
<.001 \\
.03 \\
\text { NS } \\
\end{array}$ \\
\hline $\begin{array}{l}\text { Model 3a: Final Model Time } \\
2\end{array}$ & $\begin{array}{l}F(8,326)=30.21 \\
\mathrm{p}<.001 \\
\mathrm{R}^{2}=.43\end{array}$ & & & & & \\
\hline 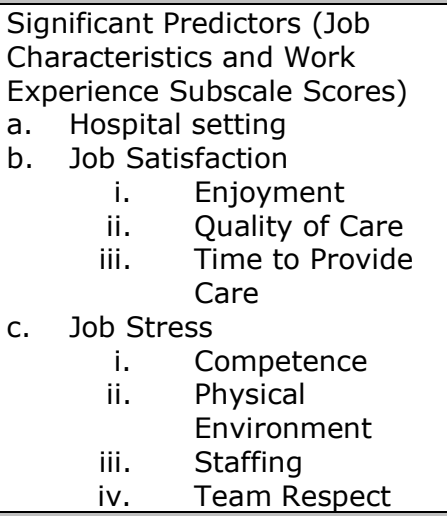 & & $\begin{array}{l}3.72 \\
.85\end{array}$ & $\begin{array}{l}1.51 \\
.11\end{array}$ & .11 & $\begin{array}{l}- \\
2.12 \\
- \\
2.88\end{array}$ & $\begin{array}{l}.01 \\
<.001 \\
\text { NS } \\
\text { NS } \\
\text { NS } \\
\text { NS } \\
.04 \\
.004\end{array}$ \\
\hline $\begin{array}{l}\text { Model 3c: Final Model Time } \\
3\end{array}$ & $\begin{array}{l}F(8,296)=28.09 \\
p<.001 \\
R^{2}=.43\end{array}$ & & & & & \\
\hline 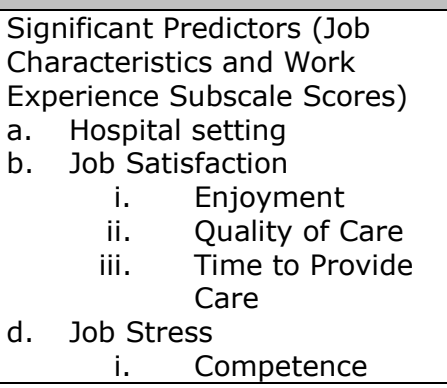 & & $\begin{array}{l}4.42 \\
1.91\end{array}$ & $\begin{array}{l}1.63 \\
.14\end{array}$ & $\begin{array}{l}.12 \\
.46\end{array}$ & $\begin{array}{l}2.72 \\
8.32\end{array}$ & $\begin{array}{l}.01 \\
<.001 \\
\text { NS } \\
\text { NS } \\
\text { NS } \\
.005 \\
\text { NS }\end{array}$ \\
\hline
\end{tabular}

Journal for Nurses in Staff Development, Vol. 28, No. 3 (Jay/June 2012): pg. 108-119. DOI. This article is (C Lippincott Williams \& Wilkins, Inc. and permission has been granted for this version to appear in e-Publications@Marquette. Lippincott Williams \& Wilkins, Inc. does not grant permission for this article to be further copied/distributed or hosted elsewhere without the express permission from Lippincott Williams \& Wilkins, Inc. 
NOT THE PUBLISHED VERSION; this is the author's final, peer-reviewed manuscript. The published version may be accessed by following the link in the citation at the bottom of the page.

\begin{tabular}{|c|l|l|l|l|l|l|}
\hline Models and Variables & Model Statistics & $\boldsymbol{\beta}$ & $\begin{array}{l}\text { SE } \\
\boldsymbol{\beta}\end{array}$ & $\begin{array}{l}\text { Standar- } \\
\text { dized } \boldsymbol{\beta}\end{array}$ & $\boldsymbol{t}$ & $\boldsymbol{p}$ \\
\hline ii. $\begin{array}{c}\text { Physical } \\
\text { Environment }\end{array}$ & & & & & & NS \\
iii. Staffing & & & & & & \\
iv. Team Respect & & & & & & \\
\hline
\end{tabular}

Journal for Nurses in Staff Development, Vol. 28, No. 3 (Jay/June 2012): pg. 108-119. DOI. This article is (C Lippincott Williams \& Wilkins, Inc. and permission has been granted for this version to appear in e-Publications@Marquette. Lippincott Williams \& Wilkins, Inc. does not grant permission for this article to be further copied/distributed or hosted elsewhere without the express permission from Lippincott Williams \& Wilkins, Inc. 
NOT THE PUBLISHED VERSION; this is the author's final, peer-reviewed manuscript. The published version may be accessed by following the link in the citation at the bottom of the page.

\section{Figure 1. Conceptual Framework for Study}

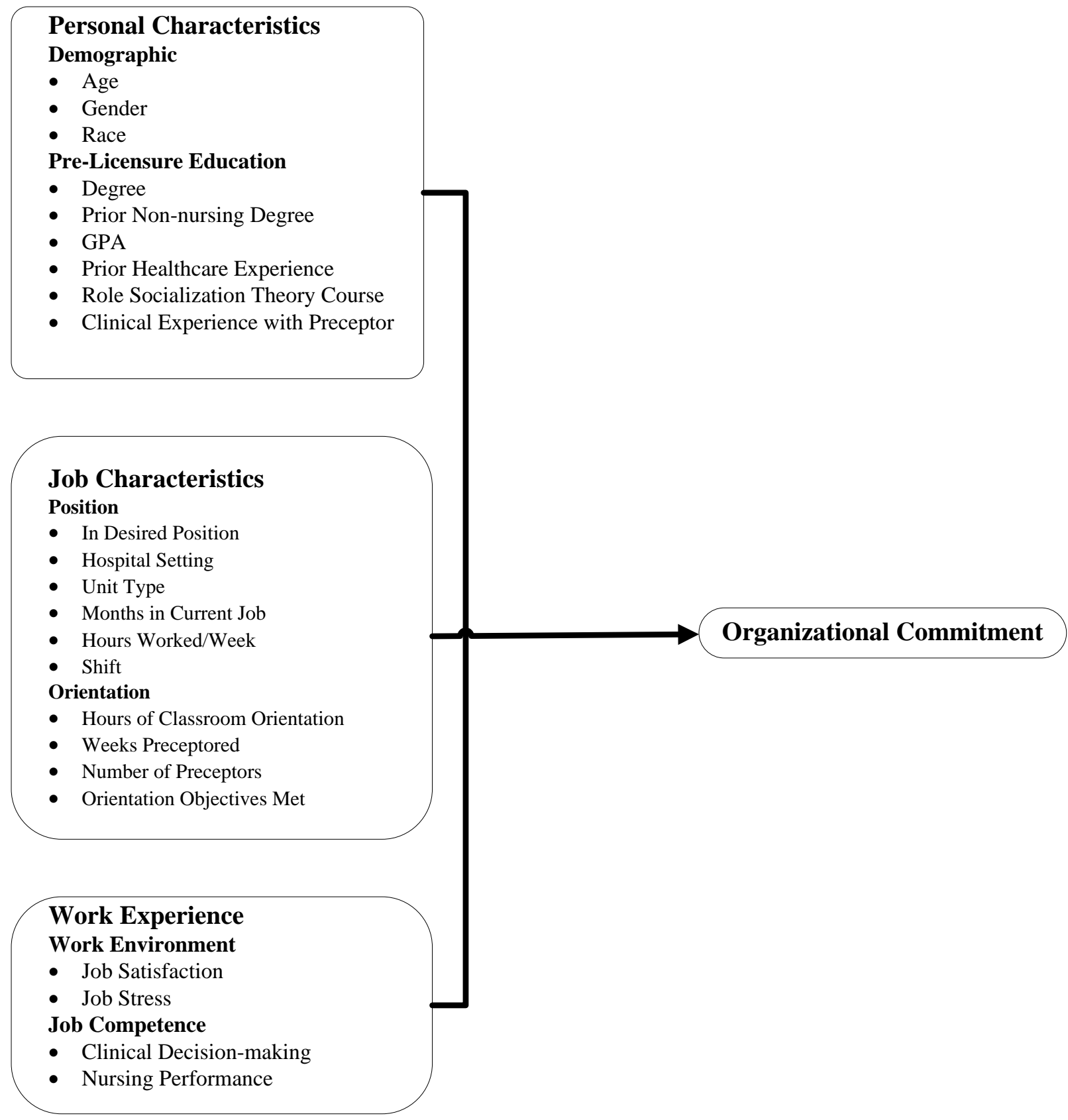

Journal for Nurses in Staff Development, Vol. 28, No. 3 (Jay/June 2012): pg. 108-119. DOI. This article is (C) Lippincott Williams \& Wilkins, Inc. and permission has been granted for this version to appear in e-Publications@Marquette. Lippincott Williams \& Wilkins, Inc. does not grant permission for this article to be further copied/distributed or hosted elsewhere without the express permission from Lippincott Williams \& Wilkins, Inc. 